\title{
New record of Anthopleura radians Spano \& Häussermann, 2017 (Cnidaria: Actiniaria: Actiniidae) from the Mexican Pacific
}

\author{
Aurora Vassallo-Avalos ${ }^{1,3}$, Fabián H. Acuña ${ }^{2,4}$, Ricardo González-Muñoz ${ }^{2}$ \& Gerardo Rivas ${ }^{1}$ \\ ${ }^{1}$ Laboratorio de Zoología Acuática, Departamento de Biología Comparada, Facultad de Ciencias \\ Universidad Nacional Autónoma de México, Ciudad Universitaria, Ciudad de México, México \\ ${ }^{2}$ Laboratorio de Biología de Cnidarios, Instituto de Investigaciones Marinas y Costeras (IIMyC) CONICET \\ Facultad de Ciencias Exactas y Naturales, Universidad Nacional de Mar del Plata \\ Mar del Plata, Argentina \\ ${ }^{3}$ Posgrado en Ciencias del Mar y Limnología, Universidad Nacional Autónoma de México \\ Ciudad Universitaria, Ciudad de México, México \\ ${ }^{4}$ Estación Científica Coiba (Coiba-AIP), Clayton, Panamá, República de Panamá \\ Corresponding author: Gerardo Rivas (gerardorivas@ ciencias.unam.mx)
}

\begin{abstract}
As part of a biodiversity study on intertidal invertebrates, several sea anemones from the west coast of the Baja California Peninsula were collected in June 2016. The taxonomic features of four specimens agree well with those of the species Anthopleura radians, a recently described sea anemone from northern Chile. This study is the first published report on this species outside the range of distribution documented in the original description, including new images of $A$. radians' external and internal features and complete characterization of their cnidae. Differences between $A$. radians from other species of the genus reported from the eastern Pacific are also discussed.
\end{abstract}

Keywords: Anthopleura radians; Actiniaria; sea anemone; intertidal; bentos; Baja California; México

Sea anemones of genus Anthopleura Duchassaing de Fonbressin \& Michelotti, 1860, are traditionally distinguished from other family members Actiniidae Rafinesque, 1815 , by having both acrorhagi and adhesive verrucae arranged in longitudinal endocoelic rows on the column (Daly et al., 2017). There are currently 47 known valid species within the genus (Daly \& Fautin, 2019), five of which were previously reported in the Gulf of California and the Baja California Peninsula, México: A. artemisia (Pickering in Dana, 1846), A. dowii Verril, 1869, A. elegantissima (Brandt, 1835), A. sola Pearse \& Francis, 2000, and A. xanthogrammica (Brandt, 1835) (Carlgren, 1951; Gotshall \& Laurent, 1979; Brusca, 1980; McFadden et al., 1997; Pearse \& Francis, 2000; Daly, 2004; Hendrickx et al., 2005; Kerstitch \& Bertsch, 2007; Barragán et al., 2019).

As part of a biodiversity study on intertidal invertebrates, several sea anemones from the west coast of the Baja California Peninsula were collected in June
2016. The taxonomic diagnostic features of some of these specimens agree well with those of Anthopleura radians Spano \& Häussermann, 2017, a recently described species of sea anemone from the northern coast of Chile (Spano \& Häussermann, 2017).

In the present study, we document the first record of A. radians in the Mexican Pacific from specimens collected in Punta Eugenia in Baja California Sur (Fig. 1). A short description with images of living specimens, internal anatomy, and cnidae are provided, and differences between $A$. radians from other species of genus Anthopleura reported in the eastern Pacific are discussed. This report presents the sixth species of genus Anthopleura in the region.

Four specimens collected in tide pools were taken to the laboratory and kept in an aquarium to photograph their color while alive. They were later relaxed in 7\% $\mathrm{MgCl}_{2}$ seawater solution, subsequently fixed in $10 \%$ seawater formalin, and stored in $70 \%$ ethanol (Häussermann, 2004a). Cnidae capsules were identified

Corresponding editor: Laura Schejter 


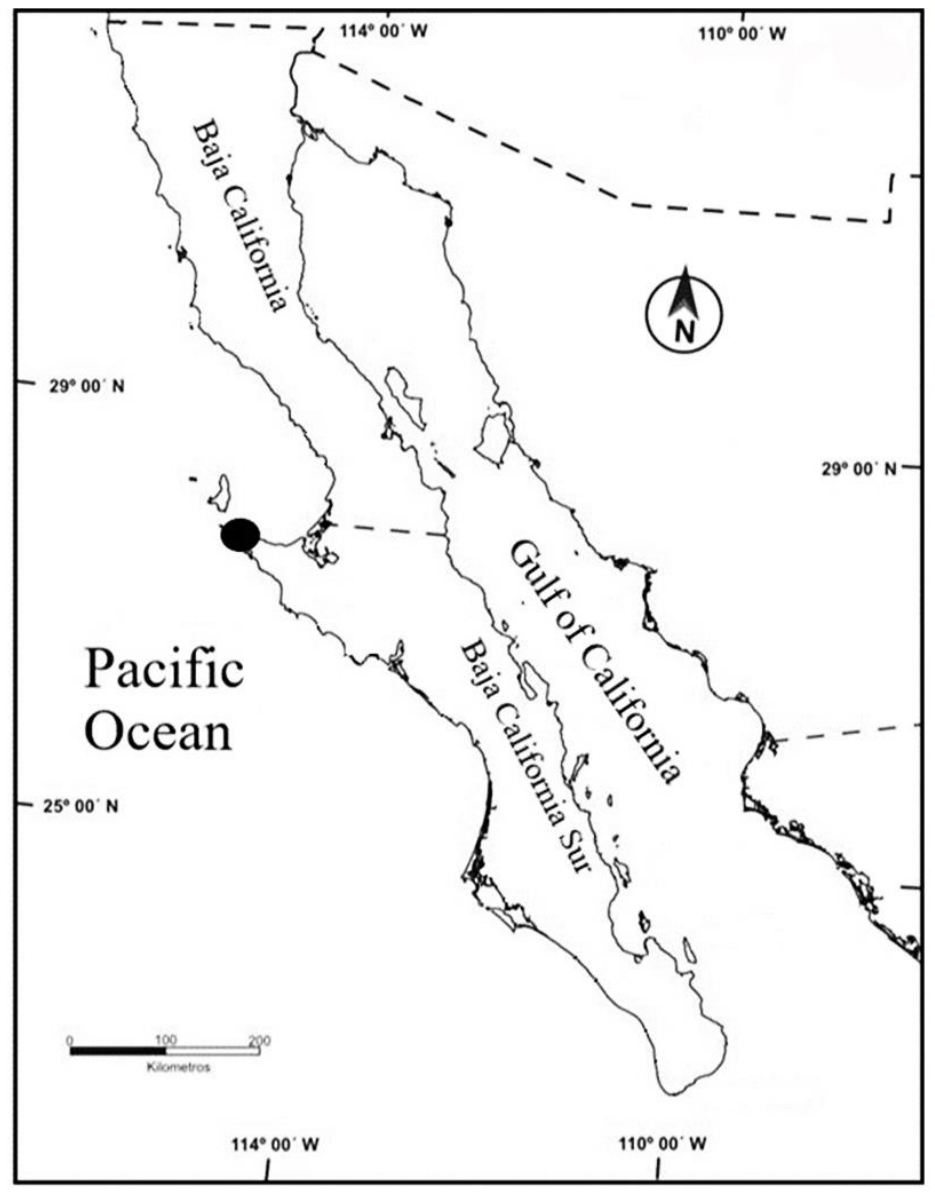

Figure 1. Map of the Baja California Peninsula. Black circle indicates Punta Eugenia, Baja California Sur. Modified from Cupul-Magaña et al. (2017).

in squash preparations of tissue from tentacles, marginal projections, actinopharynx, column, and filaments. The length and width of at least 20 undischarged capsules of each type of cnidae detected in each tissue were measured in three specimens. We followed the cnidae terminology implemented by Sanamyan et al. (2012) and Gusmão et al. (2018, 2019), which combines the Weill classification (1934), modified by Carlgren (1940), thereby differentiating basitrichs from microbasic $b$-mastigophores, with that of Schmidt (1969, 1972, 1974), which captured the underlying variation seen in rhabdoids. Histological serial sections were prepared (10 to $12 \mu \mathrm{m}$ thick) to observe the internal morphology, with paraffin embedding, and stained with hematoxylin-eosin (Estrada et al., 1982). Voucher specimens were deposited in the Collection of Aquatic Invertebrates at the Universidad Nacional Autónoma de México (UNAM) under registration code IAFCUNAM. Specimen collection numbers are given in brackets. Taxonomic treatment follows the systematic arrangement proposed by Rodríguez et al. (2014).
Systematics

Order Actiniaria Hertwig, 1882

Suborder Enthemonae Rodríguez \& Daly, 2014 in Rodríguez et al. (2014)

Superfamily Actinioidea Rafinesque, 1815

Family Actiniidae Rafinesque, 1815

Genus Anthopleura Duchassaing de Fonbressin \& Michelotti, 1860

Species Anthopleura radians Spano \& Häussermann, 2017

Material examined: four specimens from Punta Eugenia, Baja California Sur $\left(27^{\circ} 51^{\prime} 18^{\prime \prime N}\right.$, $\left.115^{\circ} 04^{\prime} 20^{\prime \prime} \mathrm{W}\right)$, June 21, 2016 [IAFCUNAM-AN0053], A. Vassallo-Avalos \& C. Conejeros-Vargas, collectors.

Coloration: oral disc olive-green to brown in ground color, with white or light yellow and black radial marks forming a radial alternate concentric pattern (resembling a checkerboard pattern) (Figs. 2a-b); mouth orange. Tentacles olive-green, internal darker than ex- 


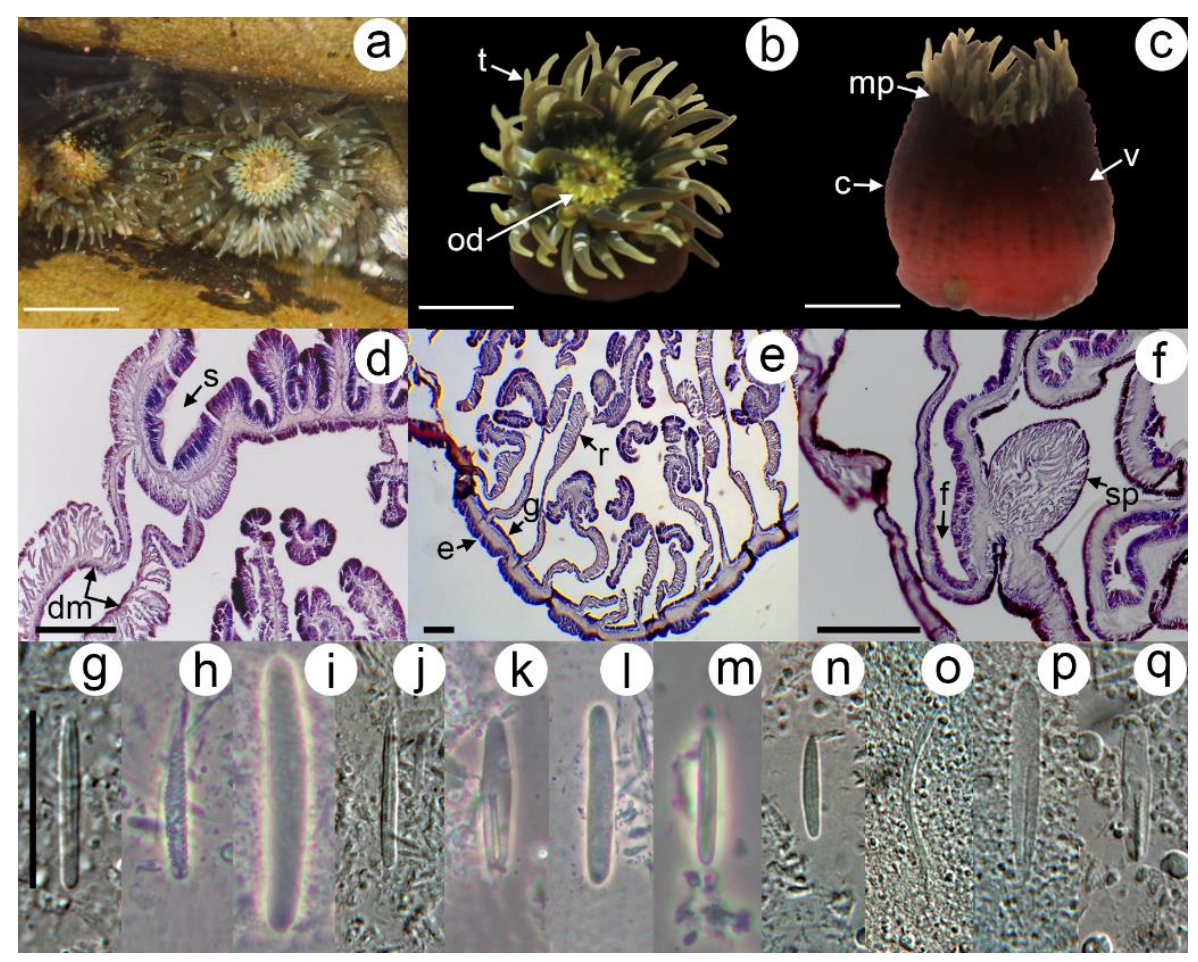

Figure 2. Anthopleura radians Spano \& Häussermann, 2017. a-b) oral disc view with tentacles expanded, c) lateral view showing column and longitudinal rows of verrucae, d) cross-section through the distal column, detail of siphonoglyph, e) cross-sections through proximal column showing pairs of mesenteries, f) longitudinal section through margin, detail of marginal sphincter. Cnidae.- tentacles, g) basitrich, h) spirocyst; acrorhagi, i) holotrich; actinopharynx, j) basitrich, k) microbasic $p$-mastigophore B1; column, 1) holotrich, $\mathrm{m}$ ) basitrich; filaments, $\mathrm{n}$ ) basitrich, o) rod-like basitrich, p) microbasic $b$-mastigophore, q) microbasic $p$-mastigophore B1. Abbreviatures c: column, dm: directive mesenteries, e: epidermis, $\mathrm{f}$ : fosse, g: gastrodermis, mp: marginal projection, od: oral disc, r: retractor muscles, s: siphonoglyph, sp: sphincter, t: tentacles, v: verrucae. Scale bars: a-c) $10 \mathrm{~mm}, \mathrm{~d}-\mathrm{f}) 200 \mu \mathrm{m}, \mathrm{g}-\mathrm{q}) 20 \mu \mathrm{m}$.

ternal, with white spots on the oral side, and their bases dark brown (Figs. 2a-b). Column dark red to salmon, with verrucae reddish to dark red (Fig. 2c), and acrorhagi generally lighter in color. Pedal disc light pink to salmon.

External anatomy: tentacles thin, blunt, smooth, hexamerously arranged in four cycles (about 48 tentacles in specimens examined) (Figs. 2a-b). Inner tentacles slightly longer than outer ones, but shorter than the diameter of the oral disc. Mouth small, rounded. Deep fosse. Column 8-13 mm height, 4-9 mm diameter in preserved specimens. Verrucae are arranged in 18 to 24 longitudinal rows from margin to just above limbus (Fig. 2b), some more protruding near the margin, distal verrucae larger and more prominent than proximal ones. Each marginal projection with one to three verrucae on its outer surface and a single acrorhagi on the inner edge. Pedal disc well-developed, 6-13 $\mathrm{mm}$ in diameter, adherent, irregular, and broader than the column.
Internal anatomy: actinopharynx with folds, with 2-3 siphonoglyphs attached to a pair of directive mesenteries (Fig. 2d). Mesenteries arranged in three cycles: first cycle perfect, second and third imperfect (Fig. 2e); gametogenic tissue not observed in specimens examined. More mesenteries proximally than distally. Retractor muscles diffuse (Fig. 2e), elongated, sometimes reniform. Parietobasilar and basilar muscles welldeveloped. Marginal sphincter muscle endodermal, circumscribed, and palmate (Fig. 2f). Mesoglea thickened $(49 \mu \mathrm{m})$, double the width of the epidermis $(28 \mu \mathrm{m})$ (Fig. 2e). Longitudinal muscles of tentacles ectodermal. Azooxanthellate.

Cnidom: spirocysts, basitrichs, holotrichs, microbasic $p$-mastigophores $\mathrm{B} 1$, and microbasic $b$-mastigophores (Figs. 2g-q). See Table 1 for the sizes and distribution of cnidae.

Natural history: Column is usually hidden in holes or crevices in rocky intertidal (Fig. 2a). Associated fauna was composed of holothuroids and gastropods. 
Table 1. Comparison of cnidae sizes ranges (length $\mathrm{x}$ width) and distribution of cnidae of Anthopleura radians, between Spano \& Häussermann (2017) and the present study. $\mathrm{m}_{\mathrm{l}}$ and $\mathrm{m}_{\mathrm{w}}$ are the means of length and width, respectively; $\mathrm{N}$ is the proportion of animals examined with the respective type of cnidae present; $\mathrm{n}$ is the number of capsules measured. Capsule sizes in micrometers $(\mu \mathrm{m})$.

\begin{tabular}{|c|c|c|c|c|c|c|c|c|c|}
\hline \multirow[t]{2}{*}{ Tissue } & \multirow[t]{2}{*}{ Cnidae } & \multicolumn{2}{|c|}{$\begin{array}{c}\text { Anthopleura radians } \\
\text { Spano \& Häussermann (2017) }\end{array}$} & \multicolumn{6}{|c|}{$\begin{array}{l}\text { Anthopleura radians } \\
\text { Present study }\end{array}$} \\
\hline & & Length $(\mu \mathrm{m})$ & Width $(\mu \mathrm{m})$ & Length $(\mu \mathrm{m})$ & Width $(\mu \mathrm{m})$ & $m_{1}$ & $\mathrm{~m}_{\mathrm{w}}$ & $\mathrm{N}$ & $\mathrm{n}$ \\
\hline \multirow[t]{2}{*}{ Tentacles } & Basitrich & $11.2-20.6$ & $1.5-3.2$ & $14.0-25.0$ & $1.5-2.5$ & 19.7 & 2.0 & $3 / 3$ & 80 \\
\hline & Spirocyst & $9.2-24.0$ & $1.4-3.0$ & $12.0-28.0$ & $2.0-3.0$ & 20.0 & 2.4 & $3 / 3$ & 80 \\
\hline Acrorhagi & Holotrich & $22.3-38.4$ & $2.8-6.2$ & $29.0-50.0$ & $3.40-6.0$ & 39.1 & 4.3 & $3 / 3$ & 80 \\
\hline \multirow[t]{2}{*}{ Actinopharynx } & Basitrich & $11.6-23.9$ & $1.7-3.1$ & $11.0-29.0$ & $1.7-4.0$ & 22.9 & 2.6 & $3 / 3$ & 80 \\
\hline & Microbasic $p$-mastigophore B1 & $13.3-21.1$ & $3.0-5.6$ & $12.8-27.0$ & $3.0-7.5$ & 22.3 & 5.4 & $3 / 3$ & 80 \\
\hline \multirow[t]{3}{*}{ Column } & Holotrich & $11.7-26.7$ & $1.6-5.0$ & $11.8-22.7$ & $2.0-7.5$ & 17.5 & 3.7 & $3 / 3$ & 61 \\
\hline & Basitrich & $8.3-10.0$ & $1.4-2.1$ & - & - & - & - & - & - \\
\hline & Basitrich & $10.5-20.4$ & $1.5-2.6$ & $10.0-20.2$ & $1.4-3.0$ & 14.2 & 2.0 & $3 / 3$ & 80 \\
\hline \multirow[t]{6}{*}{ Filaments } & Basitrich & $11.9-23.3$ & $1.8-3.3$ & $10.0-33.0$ & $1.5-3.0$ & 14.3 & 2.0 & $3 / 3$ & 80 \\
\hline & Rod-like basitrich & $17.5-42.0$ & $1.2-2.2$ & $21.0-72.0$ & $1.0-2.0$ & 38.0 & 1.8 & $2 / 3$ & 64 \\
\hline & Microbasic $b$-mastigophore & $18.0-35.0$ & $2.6-6.3$ & $20.0-38.0$ & $2.2-5.0$ & 29.3 & 4.1 & $3 / 3$ & 80 \\
\hline & Microbasic $p$-mastigophore B1 & & & & & & & & \\
\hline & & 12.3-17.9, & $2.1-3.7$ & $8.0-27.0$ & $3.0-7.0$ & 20.8 & 4.2 & $3 / 3$ & 80 \\
\hline & & $14.0-22.4$ & $2.7-6.8$ & - & - & - & - & - & - \\
\hline
\end{tabular}

No other species of sea anemones were observed around or in the same crevice where A. radians' specimens were found. However, individuals of $A$. elegantissima were observed in the surrounding tide pools. Spano \& Häussermann (2017) mention that $A$. radians can be locally abundant, apparently in clonal populations.

Geographic distribution: Pan de Azúcar (261's, $\left.70^{\circ} 39^{\prime} \mathrm{W}\right)$ to Puerto Aldea ( $\left.30^{\circ} 17^{\prime} \mathrm{S}, 71^{\circ} 36^{\prime} \mathrm{W}\right)$, Chile (Spano \& Häussermann, 2017). This is the first record in Mexico, in Punta Eugenia, Baja California Sur.

Remarks: taxonomic characters of the specimens of A. radians from Punta Eugenia generally agree with those of the Chilean specimens described by Spano \& Häussermann (2017) with few exceptions. We observed the mouth with an orange coloring rather than pink, and the tentacles olive-green with white spots, but without purplish flashes (Figs. 2a-b). Furthermore, we observed some specimens with three siphonoglyphs rather than only two. However, Spano \& Häussermann (2017) reported sporadic asymmetries of siphonoglyphs accompanied by column scars, suggesting that A. radians are capable of reproducing asexually. We did not observe gametogenic tissue in the specimens examined, while Spano \& Häussermann (2017) found it only in perfect mesenteries. We only observed one size category of basitrichs in the column, while Spano \& Häussermann (2017) mention two size categories in this structure (Table 1).

Similarly, we only observed one size category for the basitrichs and one category for the microbasic $p$ mastigophores B1 in the filaments, while Spano \& Häussermann (2017) considers two size categories for each of these two types of cnidae in the same structure. However, in all these cases, the cnidae size ranges measured from Punta Eugenia specimens overlap well with those of the Chilean specimens, regardless of the size category assigned. Table 1 summarizes a comparison of cnidae size ranges between specimens from Baja California Sur, Mexico, with those from the Chilean coast. All other external and internal anatomical characteristics observed in the Mexican specimens agree well with those described for the species.

According to Spano \& Häussermann (2017), the checkerboard-like pattern coloration on the oral disc is one of the main characteristics that distinguish $A$. radians from other Anthopleura species distributed in the Pacific Ocean. Among Anthopleura species reported in the southeast Pacific, A. hermaphroditica (Carlgren, 1899) is distributed along the coast of Chile and presents a brown-colored oral disc which varies from olive green to grayish ocher (Yanagi \& Daly, 2004; Spano et al., 2013). A. mariscali Daly \& Fautin, 2004 has been reported from the Galapagos Islands and the Pacific coast of Costa Rica and presents a brown colored oral disc with pale lines marking the mesenterial insertions (Daly \& Fautin, 2004; Fautin et al., 2007; Quesada et al., 2017). A. nigrescens (Verrill, 1928) presents a dark-gray or brown oral disc, with dark lines marking mesenterial insertions, and is distributed in the Indian Ocean, the western and central Pacific, the Galapagos Islands, and the coast of Costa Rica (Dunn, 1974; Fautin et al., 2007; Acuña et al., 2012). Regarding the species of Anthopleura reported in New Zealand, A. inconspicua (Hutton, 1879) presents an olive-brown oral disc with darker lines 
New record of Anthopleura radians from Mexico

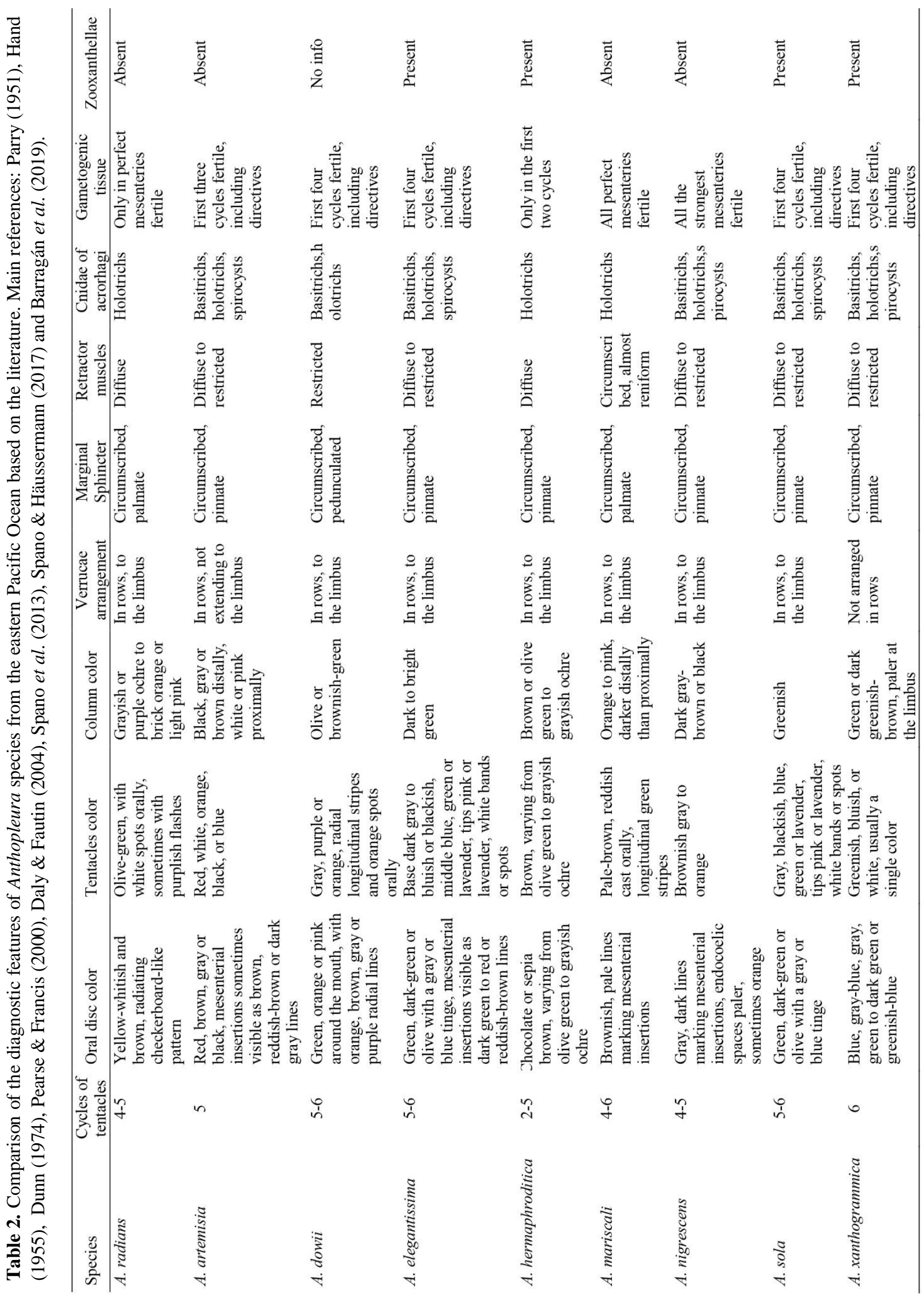


along the mesenteries, A. rosea (Stuckey \& Walton, 1910) has a creamy white oral disc with 12 dark brown rays running out from the peristome, A. kohli Carlgren, 1930 is reddish or white (in alcohol). Moreover, the oral disc of A. aureoradiata (Stuckey, 1909) has yellow marks on the peristome corresponding to the primary endocoels (Carlgren, 1924; Parry, 1951; Spano \& Häussermann, 2017), although Spano \& Häussermann (2017) suggested that $A$. aureoradiata and $A$. hermaphroditica should be synonymized. Also, the species A. minima (Stuckey \& Walton, 1910) exhibits an oral disc coloration pattern similar to that of $A$. radians, with a rose-color center surrounded by a "complicated pattern of light and dark olive-green and gray" (Parry, 1951). Spano \& Häussermann (2017) mention that $A$. minima could be a senior synonym of A. radians; however, more information on the internal anatomy and cnidae of A. minima is needed to confirm this hypothesis.

As for the species of Anthopleura reported in the northern Pacific, A. artemisia presents a red, brown, gray, or black oral disc, sometimes with reddish-brown or dark-gray lines marking the mesenterial insertions (Hand, 1955). A. dowii presents a green, orange, or pink oral disc with brown, gray or purple radial lines (Hand, 1955; Barragán et al., 2019), in A. elegantissima and A. sola the oral disc is usually a shade of green, dark-green or olive with grey or blue tinge, and mesenterial insertions can be visible as dark green to red or reddishbrown lines (Hand, 1955). A. xanthogrammica presents a blue, gray-blue, and green to dark-green oral disc (Hand, 1955). Unlike A. radians, A. elegantissima, A. hermaphroditica, A. sola, and A. xanthogrammica harbor zooxanthellae. Also, A. radians and A. mariscali present a circumscribed marginal sphincter palmate, rather than pinnate as in the rest of these species. Furthermore, A. nigrescens lacks directive mesenteries (Dunn, 1974; Fautin et al., 2007; Acuña et al., 2012), A. mariscali has circumscribed rather than diffuse retractor muscles (Daly \& Fautin, 2004; Fautin et al., 2007), and the longitudinal rows of verrucae do not extend to the limbus in A. artemisia (Hand, 1955), unlike the common pattern of most species of Anthopleura, including A. radians. Table 2 summarizes the main characteristics to distinguish among $A$. radians and other species of Anthopleura from the eastern Pacific.

As far as we know, there are other two more sightings of $A$. radians outside of the type locality, in Bahía de Ilo, Perú (Castillo-Acobo, 2019), and in New Zealand (iNaturalist, 2020). However, these records' certainty needs to be confirmed with a complete taxonomic revision of those specimens. If these records are true, then the nearest previous record for A. radians from the new record in Baja California Sur is about
6,900 km away, in Bahía de Ilo, leaving a significant gap in its known distribution. Other species of sea anemones are also widely distributed on the eastern Pacific coast, such as Phymactis papillosa (Lesson, 1830), which is recorded from the Baja California peninsula to southern Chile (Häussermann, 2004b). However, taxonomic studies of sea anemones in the central Pacific are scarce. Further studies on actiniarians in coastal areas between Mexico and Chile are needed to reveal whether the distribution of species such as A. radians and $P$. papillosa is continuous or patchy (Häussermann, 2004b).

\section{ACKNOWLEDGMENTS}

We thank Carlos Conejeros, Mauricio Carmona, Rogelio Aguilar, Alma Islas, and Omar Lagunas for assistance in the field. Rosario Ortiz and Patricia Rivas for assistance in histological techniques. This work was partially funded by grants from projects DGAPAUNAM-PAPIIT IN 224217 and IN218414. The first author was supported by a Master's degree fellowship from the Consejo Nacional de Ciencia y Tecnología (CONACYT) in the Postgraduate Program of Ciencias del Mar y Limnología, UNAM.

\section{REFERENCES}

Acuña, F.H., Alvarado, J., Garese, A. \& Cortés, J. 2012 First record of the sea anemone Anthopleura nigrescens (Cnidaria, Actiniaria, Actiniidae) on the Pacific coast of Central America. Marine Biodiversity Records, 5: 1-3. doi: 10.1017/S175526721200022X

Barragán, Y., Sánchez, C. \& Rodríguez, E. 2019. First inventory of sea anemones (Cnidaria: Actiniaria) from La Paz Bay, southern Gulf of California (Mexico). Zootaxa, 4559: 501-549. doi: 10.11646/zootaxa.4559. 3.4

Brusca, R.C. 1980. Common intertidal invertebrates of the Gulf of California. University of Arizona Press, Tucson, Arizona.

Castillo-Acobo, L.N. 2019. Estructura comunitaria del macrozoobentos de la Caleta Puerto Inglés, Bahía de Ilo - Moquegua durante el verano del 2017. Tesis de Biología, Universidad Nacional de San Agustín de Arequipa, Arequipa, 197 pp.

Carlgren, O. 1924. Actiniaria from New Zealand and its subantartic Islands [article XXI in papers from Dr. Th. Mortensen's Pacific Expedition 1914-1916]. Videnskabelige Meddelelser fra Dansk Naturhistorisk Forening (Copenhagen), 77: 179-261.

Carlgren, O. 1940. A contribution to the knowledge of the structure and distribution of the cnidae in the Anthozoa. Kungliga Fysiografiska Sällskapets Handlingar, 3: 3-62. 
Carlgren, O. 1951. The actinian fauna of the Gulf of California. Smithson. Proceedings of the United States National Museum, 101: 415-449.

Cupul-Magaña, L.A., Guardado-France R., Gil-Silva, E., Ledesma-Vázquez, J., Ávila-Serrano, G.E., GonzálezYajimoich, O.E. \& Chee-Barragán, A. 2017. Interacción océano-tierra en la generación de sedimentos de playas y dunas. Ciencia y Sociedad, 20(85): 4 pp.

Daly, M. 2004. Anatomy and taxonomy of three species of sea anemones (Cnidaria: Anthozoa: Actiniidae) from the Gulf of California, including Isoaulactinia hespervolita Daly, n. sp. Pacific Sciences, 3: 377-390. doi: 10.1353/psc.2004.0030

Daly, M. \& Fautin, D.G. 2004. Anthopleura mariscali, a new species of sea anemone (Cnidaria: Anthozoa: Actiniaria) from the Galapagos Islands. Zootaxa, 416: 1-8.

Daly, M. \& Fautin, D.G. 2019. World list of Actiniaria. Actiniaria. World Register of Marine Species. [http://www.marinespecies.org/aphia.php?p=taxdetail sandid=1360]. Reviewed: March 6, 2019.

Daly, M., Crowley, L.M., Larson, P., Rodríguez, E., Heestand-Saucier, E. \& Fautin, D.G. 2017. Anthopleura and the phylogeny of Actinioidea (Cnidaria: Anthozoa: Actiniaria). Organisms Diversity \& Evolution, 17: 545-564. doi: 10.1007/s13127-0170326-6

Dunn, D.F. 1974. Redescription of Anthopleura nigrescens (Coelenterata, Actiniaria) from Hawaii. PacificScience, 28(4): 377-382.

Estrada, E., Peralta, L. \& Rivas, P. 1982. Manual de técnicas histológicas. AGT Editor, Ciudad de México.

Fautin, D.G., Hickman, C.P., Daly, M. \& Molodtsova, T. 2007. Shallow-water sea anemones (Cnidaria: Anthozoa: Actiniaria) and tube anemones (Cnidaria: Anthozoa: Ceriantharia) of the Galápagos Islands. Pacific Science, 61(4): 549-573. doi: 10.2984/15346188(2007)61[549: SSACAA]2.0.CO;2

Gotshall, W.D. \& Laurent, L.L. 1979. Pacific coast subtidal marine invertebrates. A fishwatcher's guide. Sea Challengers, California.

Gusmão, L.C., Grajales, A. \& Rodríguez, E. 2018. Sea anemones through $\mathrm{X}$-rays: visualization of two species of Diadumene (Cnidaria, Actiniaria) using micro-CT. American Museum Novitates, 3907: 1-45. doi: 10.1206/3907.1

Gusmão, L.C., Rodríguez, E. \& Daly, M. 2019. Description of Calliactistigris sp. nov.: reconciling taxonomy and phylogeny in hermit-crab symbiotic anemones (Cnidaria: Actiniaria: Hormathiidae).
Organisms Diversity \& Evolution, 19(4): 567-583. doi: 10.1007/s13127-019-00414-2

Hand, C. 1955. The sea anemones of central California part II. The endomyarian and mesomyarian anemones. Wasmann Journal of Biology, 13(1): 37-99.

Häussermann, V. 2004a. Identification and taxonomy of soft-bodied hexacorals exemplified by Chilean sea anemones; including guidelines for sampling, preservation, and examination. Journal of the Marine Biological Association of the United Kingdom, 84: 931-936. doi: 10.1017/S0025315404010215h

Häussermann, V. 2004b. Re-description of Phymactispapillosa (Lesson, 1830) and Phymantheapluvia (Drayton in Dana, 1846) (Cnidaria: Anthozoa), two common actiniid sea anemones from the southeast Pacific with a discussion of related genera. Zoologische Mededelingen Leiden, 78(23): 345-381.

Hendrickx, M.E., Brusca, R.C. \& Findley, L.T. 2005. Listado y distribución de la macrofauna del Golfo de California, México. Parte 1. Invertebrados. ArizonaSonora Desert Museum, Arizona.

iNaturalist. 2020. Anthopleura radians. [https://www.inaturalist.org/guidetaxa/824922]. Reviewed: February 26, 2020.

Kerstitch, A. \& Bertsch, H. 2007. Sea of Cortez marine invertebrates. A guide for the Pacific Coast, México to Perú. Sea Challengers, California.

McFadden, C.S., Grosberg, R.K., Cameron, B.B., Karlton, D.P. \& Secord, D. 1997. Genetic relationships within and between clonal and solitary forms of the sea anemone Anthopleura elegantissima revisited: evidence for the existence of two species. Marine Biology, 128: 127-139. doi: 10.1007/s002270050

Parry, G. 1951. The Actiniaria of New Zealand. A checklist of recorded and new species. A review of the literature and a key to the commoner forms. Part 1. Records of the Canterbury Museum, 6(1): 83-119.

Pearse, V. \& Francis, L. 2000. Anthopleura sola, a new species, solitary sibling species to the aggregating sea anemone, A. elegantissima (Cnidaria: Anthozoa: Actiniaria: Actiniidae). Proceedings of the Biological Society of Washington, 113: 596-608.

Quesada, A.J., Acuña, F.H. \& Cortés, J. 2017. First record of the sea anemone Anthopleura mariscali outside the Galápagos Archipelago. Marine Biodiversity, 47: 225228.

Rodríguez, E., Barbeitos, M.S., Brugler, M.R., Crowley, L.M., Grajales, A., Gusmão, L., Häussermann, V., Reft, A. \& Daly, M. 2014. Hidden among sea anemones: the first comprehensive phylogenetic reconstruction of the order Actiniaria (Cnidaria, Anthozoa, Hexacorallia) reveals a novel group of 
hexacorals. Plos One, 9(5): e96998. doi: 10.1371/ journal.pone.0096998

Sanamyan, N.P., Sanamyan, K.E. \& Tabachnick, K.R. 2012. The first species of Actiniaria, Spongiactis japonica gen. n., sp. n. (Cnidaria: Anthozoa) and obligate symbiont of a glass sponge. Invertebrate Zoology, 9: 127-141. doi: 10.15298/invertzool.09.2.05

Schmidt, H. 1969. Die nesselkapseln der Aktinien und ihre differential-diagnostische bedeutung. Helgoländer Wissenschaftliche Meeresuntersuchunge, 19: 287317.

Schmidt, H. 1972. Die nesselkapseln der Anthozoen und ihre bedeutung fur die phylogenetische systematik. Helgoländer Wissenschaftliche Meeresuntersuchunge, 23: 422-458.

Schmidt, H. 1974. On evolution in the Anthozoa. Proceedings of the Second International Coral Reef Symposium, 1: 533-560.

Received: 6 August 2019; Accepted: 1 June 2020
Spano, C. \& Häussermann, V. 2017. Anthopleura radians, a new species of sea anemone (Cnidaria: Actiniaria: Actiniidae) from northern Chile, with comments on other species of the genus from the South Pacific Ocean. Biodiversity and Natural History, 3: 1-11.

Spano, C., Rozbaczylo, N., Häussermann, V. \& Bravo, R. 2013. Redescription of the sea anemones Anthopleura hermaphroditica and Bunodactis hermaphroditica (Cnidaria: Anthozoa: Actiniaria) from Chile. Revista de Biología Marina y Oceanografía, 48(3): 521-534. doi:10.4067/S0718-19572013000300010

Weill, R. 1934. Contribution a l'étude des Cnidaireset de leurs nematocysts. Les Presses Universitaires de France, Paris.

Yanagi, K. \& Daly, M. 2004. The hermaphroditic sea anemone Anthopleura atodai n. sp. (Anthozoa: Actiniaria: Actiniidae) from Japan, with a redescription of $A$. hermaphroditica. Proceedings of the Biological Society of Washington, 117(3): 408-422. 